\title{
AKUNTABILITAS ADMINISTRASI PERTANAHAN DALAM PENERBITAN SERTIFIKAT
}

\author{
Muhammad Ilham Arisaputra*, Muhammad Ashri** Kasman Abdullah ${ }^{* * *}$ dan Dian Utami \\ Mas Bakar****
}

Departemen Hukum Perdata, Departemen Hukum Internasional, Departemen Hukum Tata Negara, dan Departemen Hukum Administrasi Negara

Fakultas Hukum Universitas Hasanuddin Makassar, Sulawesi Selatan, 90245

\begin{abstract}
In the publishing of certificates of land rights, the government should be able to provide legal certainty. Legal certainty can be achieved if the government's actions performed accountable. Transparency in land registration is the most important thing in the case of registration of land in order that the maintenance and services procedures run as expected by the public. The effect of the principle of transparency sustainably, it is expected that the information relating to the publishing of a certificate to be accessible to all parties so that if there is information that is considered wrong to do immediate repair.
\end{abstract}

Keywords: land administration, accountability, certificate.

\section{Intisari}

Dalam penerbitan sertifikat hak atas tanah, maka pemerintah harus dapat memberikan kepastian hukum. Kepastian hukum dapat terwujud apabila tindakan pemerintah dilakukan secara akuntabel. Transparansi dalam pendaftaran tanah merupakan hal terpenting dalam hal pendaftaran tanah agar prosedur pengurusan dan pelayanan berjalan seperti yang diharapkan oleh masyarakat. Dengan dilakukannya prinsip transparansi secara berkesinambungan, maka diharapkan informasi yang berkaitan dengan proses hingga penerbitan sertifikat dapat diakses oleh semua pihak sehingga apabila ada informasi yang dianggap keliru segera dapat dilakukan perbaikan.

Kata Kunci: administrasi pertanahan, akuntabilitas, sertifikat.

\section{Pokok Muatan}

A. Pendahuluan 277

B. Pembahasan

C. Penutup 289

Alamat korespondensi: ilhamarisaputra@gmail.com.

Alamat korespondensi: m_ashri@hotmail.com.

*** Alamat korespondensi: kasman.abdullah@yahoo.com.

***** Alamat korespondensi: dianutamimasbakar91@yahoo.com. 


\section{A. Pendahuluan}

Seiring dengan kemajuan pembangunan di segala bidang kehidupan yang juga diikuti dengan kemajuan di bidang pendidikan dan teknologi, secara tidak langsung memaksa setiap orang yang melakukan perbuatan hukum membutuhkan jaminan kepastian hukum atas perbuatannya itu. Jaminan kepastian hukum yang dimaksud meliputi ketertiban dan perlindungan hukum sehingga menimbulkan rasa aman bagi setiap perbuatan hukum yang dilakukan. Salah satu bentuk jaminan kepastian hukum di bidang pertanahan adalah dengan adanya bukti kepemilikan hak atas tanah yang disebut sertifikat.

Perkembangan hukum agraria dewasa ini khsusunya menyangkut masalah kepastian hak dan subjek hak atas tanah mendapat perhatian yang cukup serius. Hal ini antara lain dapat dilihat dalam Pasal 19 UUPA yang menyatakan bahwa untuk menjamin kepastian hak dan kepastian hukum menyangkut tanah, maka pemerintah mengadakan pendaftaran tanah. Pendaftaran tanah tersebut meliputi pengukuran, pemetaan, pendaftaran hakhak atas tanah, peralihan hak-hak tersebut kepada pihak lain, seta pemberian surat tanda bukti hak yang merupakan alat bukti kuat. ${ }^{1}$

Pemberian bukti hak yang berupa sertifikat yang sebelumnya didahului dengan pendaftaran tanah, terutama ditujukan kepada subjek hak dengan maksud agar para subjek hak tersebut memperoleh kepastian tentang haknya itu. Hal ini adalah suatu jaminan yang diberikan oleh undangundang, sehingga seharusnya setiap subjek hak atas tanah wajib melakukan pendaftaran tanahnya agar dapat mengetahui dengan jelas tentang keadaan, letak, luas, dan batas-batas tanah yang bersangkutan. Jika ternyata subjek hak tersebut tidak melakukan pendaftaran atas tanahnya, maka hal ini dapat menimbulkan kesulitan kelak di kemudian hari apabila timbul perselisihan khususnya perselisihan yang terjadi dengan pemilik tanah yang bersebelahan. Dengan kata lain dapat terjadi sengketa perbatasan tanah karena masingmasing pihak tidak mengetahui jelas batas-batas tanah miliknya sebagai akibat tidak adanya bukti pemilikan hak atas tanah (sertifikat).

Jaminan kepastian hukum hak atas tanah diatur dalam Peraturan Pemerintah Nomor 24 Tahun 1997 tentang Pendaftaran Tanah dimana dalam Pasal 3 dijelaskan mengenai tujuan pendaftaran tanah, yakni:

1) Untuk memberikan kepastian hukum dan perlindungan hukum kepada pemegang hak atas sesuatu bidang tanah, satuan rumah susun, dan hak-hak lain yang terdaftar, agar dengan mudah dapat membuktikan dirinya sebagai pemegang hak yang bersangkutan.

2) Untuk menyediakan informasi kepada pihak-pihak yang berkepentingan termasuk pemerintah, agar dengan mudah dapat memperoleh data yang diperlukan dalam mengadakan perbuatan hukum bidang-bidang tanah dan satuan-satuan rumah susun yang terdaftar.

3) Untuk terselenggaranya tertib administrasi pertanahan. ${ }^{2}$

Proses penerbitan sertifikat hak atas tanah adalah merupakan rangkaian dari sistem administrasi pertanahan. Hukum agraria apabila dilihat dari isi aturan hukum adalah hukum yang mengatur hal yang bertalian dengan tanah. Ini berarti bukan saja menyangkut pengaturan tentang hubungan hukum antara manusia dengan tanah saja tetapi juga mengatur penyelenggaraan peruntukan, penggunaan, dan penyediaan serta pemeliharaan. ${ }^{3}$ Setiap kegiatan badan atau pejabat negara dalam

\footnotetext{
Lihat Pasal 19 Undang-Undang Nomor 5 Tahun 1960 tentang Peraturan Dasar Pokok-Pokok Agraria (Lembaran Negara Republik Indonesia Tahun 1960 Nomor 104, Tambahan Lembaran Negara Republik Indonesia Nomor 2043).

Lihat Pasal 3 Peraturan Pemerintah Nomor 24 Tahun 1997 tentang Pendaftaran Tanah (Lembaran Negara Republik Indonesia Tahun 1997 Nomor 59, Tambahan Lembaran Negara Republik Indonesia Nomor 3696).

Faried Ali, 1997, Hukum Tata Pemerintahan dan Proses Legislatif Indonesia, Rajagrafindo Persada, Jakarta, hlm. 65.
} 
mengatur dan menyelenggarakan peruntukan, penggunaan, dan penyediaan, serta pemeliharaan tanah tersebut merupakan kegiatan administrasi pertanahan.

Kegiatan pendaftaran tanah yang memformalkan pemilikan tanah, baik berdasarkan bukti-bukti pemilikan maupun penguasaan atas tanah, selain menyangkut aspek yuridis dan aspek teknis, pelaksanaan pendaftaran tanah juga terkait dengan tugas-tugas keadministrasian. Dengan kata lain, dalam kegiatan pendaftaran tanah terdapat tugas-tugas penatausahaan, seperti dalam hal penetapan hak atas tanah dan pendaftaran peralihan hak tanah. Bahkan dapat dikatakan bahwa kegiatan yang menyangkut aspek yuridis atau pengumpulan data yuridis sampai kepada penerbitan buku tanah, sertifikat dan daftar umum lainnya serta pencatatan perubahan di kemudian hari hampir seluruhnya menyangkut tugas-tugas administrasi.

Jumlah luas tanah yang dapat dikuasai oleh manusia terbatas sedangkan jumlah manusia yang menginginkan tanah selalu bertambah sehingga nilai tanah semakin meningkat tinggi. Hal ini mengakibatkan timbulnya berbagai persoalan di bidang pertanahan, khususnya dalam hal kepemilikan tanah. Oleh karena itu, pemerintah dalam Pasal 5 ayat (1) butir c Ketetapan MPR Nomor IX Tahun 2001 mengadakan kebijakan pembaharuan di bidang agraria, yaitu "Menyelenggarakan pendataan pertanahan melalui inventarisasi dan registrasi penguasaan, pemilikan, penggunaan dan pemanfaatan tanah secara komprehensif dan sistematis dalam rangka pelaksanaan landreform" “.

Sengketa tanah secara administratif timbul sebagai akibat dari sistem administrasi pertanahan. Akuntabilitas administrasi pertanahan idealnya akan memperjelas kepemilikan hak atas tanah melalui bukti kepemilikan hak atas tanah yang dikeluarkan oleh kantor pertanahan, yakni berupa sertifikat hak atas tanah. Lahirnya sertifikat hak atas tanah ini bersumber dari adanya alas hak yang berupa rincik ataupun akta-akta di bidang pertanahan sebagai akibat dari adanya perbuatan hukum seperti jual beli, tukar menukar, hibah, waris, dan lain-lain sebagainya.

Tidak akuntabelnya administrasi pertanahan berakibat pada timbulnya berbagai permasalahan mengenai bukti kepemilikan hak atas tanah, seperti masalah sertifikat ganda. Tidak akuntabelnya administrasi pertanahan berdampak pada tidak transparannya administrasi pertanahan sehingga masyarakat yang membutuhkan informasi tentang suatu bidang tanah tidak bisa mendapatkannya. Tidak adanya akuntabilitas dan transparansi dalam administrasi pertanahan juga berdampak pada permasalahan bukti kepemilikan hak atas tanah termasuk pula alas hak atas tanah yang pada akhirnya menyebabkan sengketa pertanahan muncul di dalam masyarakat.

Mendiskusikan mengenai administrasi pertanahan sebagaimana dijelaskan di atas tentunya akan menyinggung tindakan pemerintah untuk mewujudkan ketatapemerintahan yang baik (good governance). Oleh karena itu, yang disoroti pada persoalan administrasi pertanahan dalam kaitannya dengan bukti kepemilikan hak atas tanah ini adalah prinsip akuntabilitas ${ }^{5}$, prinsip transparansi ${ }^{6}$, dan prinsip responsibilitas ${ }^{7}$. Penyelenggaraan administrasi pertanahan yang transparan dan responsif akan mendukung penyelenggarakan administrasi pertanahan yang akuntabel.

Berdasarkan pemaparan tersebut di atas, maka dapat dirumuskan suatu permasalahan dalam penulisan ini, yakni bagaimanakah penerapan asas

Pasal 5 ayat (1) butir c Ketetapan MPR Nomor IX/MPR/2001 tentang Pembaruan Agraria dan Pengelolaan Sumber Daya Alam. Prinsip Akuntabilitas diartikan bahwa para pembuat keputusan dalam pemerintahan, sektor swasta dan masyarakat (civil society) bertanggung jawab kepada publik dan lembaga-lembaga "stakeholders". Akuntabilitas ini tergantung pada organisasi dan sifat keputusan yang dibuat, apakah keputusan tersebut untuk kepentingan internal atau eksternal organisasi. Lihat dalam Joko Widodo, 2001, Good Governance; Telaah Dari Dimensi Akuntabilitas, Kontrol Birokrasi Pada Era Desentralisasi Dan Otonomi Daerah, Insan Cendekia, Surabaya, hlm. 25.

Prinsip Transparansi dibangun atas dasar kebebasan arus informasi. Proses-proses, lembaga- lembaga dan informasi secara langsung dapat diterima oleh mereka yang membutuhkan. Informasi harus dapat dipahami dan dapat dimonitor. Lihat dalam Joko Widodo, ibid.

Prinsip Responsibiliti diartikan bahwa Lembaga-lembaga dan proses-proses harus mencoba untuk melayani setiap "stakeholders". Lihat dalam Joko Widodo, ibid. 
transparansi dalam penerbitan sertifikat hak atas tanah untuk mewujudkan akuntabilitas administrasi pertanahan.

\section{B. Pembahasan}

Pasal 4 Ayat (2) Undang-Undang Nomor 5 Tahun 1960 tentang Peraturan Dasar PokokPokok Agraria (UUPA) menyatakan hak-hak atas tanah bukan hanya memberikan wewenang untuk mempergunakan sebagian tertentu permukaan bumi yang bersangkutan, yang disebut "tanah", tetapi juga tubuh bumi yang ada di bawahnya dan air serta ruang yang ada di atasnya. ${ }^{8}$ Dengan demikian, pengertian "tanah" meliputi permukaan bumi yang ada di daratan dan permukaan bumi yang berada di bawah air, termasuk air laut. ${ }^{9}$

Hukum agraria apabila dilihat dari isi aturan hukum adalah hukum yang mengatur hal yang bertalian dengan tanah. Ini berarti bukan saja menyangkut pengaturan tentang hubungan hukum antara manusia dengan tanah saja tetapi juga mengatur penyelenggaraan peruntukan, penggunaan, dan penyediaan serta pemeliharaan. ${ }^{10}$ Setiap kegiatan badan atau pejabat negara dalam mengatur dan menyelenggarakan peruntukan, penggunaan, dan penyediaan, serta pemeliharaan tanah tersebut merupakan kegiatan administrasi pertanahan. Dengan demikian, maka pengertian administrasi pertanahan dapat dinyatakan sebagai usaha dan kegiatan yang berkaitan dengan penyelenggaran kebijaksanaan menyangkut segala sesuatu yang berkenaan dengan tanah dan hakhak atas tanah dengan tujuan untuk menjamian kepastian hukum dan tertib pertanahan. Adapun lingkup kegiatan administrasi pertanahan adalah sebagai berikut:

\section{a. Peruntukan dan Penggunaan Tanah}

Peruntukan dan penggunaan tanah berkenaan dengan tata guna tanah. Rencana tata guna tanah dapat diartikan sebagai optimalisasi dari produktifitas bumi, air, ruang angkasa serta kekayaan alam yang terkandung di dalamnya yang dilaksanakan secara terpadu dan seimbang untuk berbagai kegiatan pembangunan, berdasarkan petapeta kemampuan yang dikeluarkan oleh BPN yang diatur dalam satu perencana tata ruang sehingga dapat memberikan manfaat bagi rakyat banyak masa kini dan masa yang akan datang. Dalam hal ini istilah tata guna tanah lebih ditekankan pada konteks penataan ruang. ${ }^{11}$

Ketentuan yuridis yang mengatur tentang penataan ruang adalah UndangUndang Nomor 26 Tahun 2007 tentang Penataan Ruang. Penyelenggaraan Penataan Ruang adalah kegiatan yang meliputi pengaturan, pembinaan, pelaksanaan, dan pengawasan penataan ruang. ${ }^{12}$ Kegiatan administrasi dalam penataan ruang terutama diterapkan pada pelaksanaan tata ruang. Tugas pelaksanaan penataan ruang meliputi perencanaan tata ruang, pemanfaatan ruang, dan pengendalian pemanfaatan ruang. ${ }^{13}$

\section{b. Penyediaan Tanah}

Kegiatan penyediaan tanah berkenaan dengan kebijakan pengadaan tanah. Dasar yuridis kebijakan pengadaan tanah adalah Undang-Undang Nomor 2 Tahun 2012 tentang Pengadaan Tanah Bagi Pelaksanaan Pembangunan Untuk Kepentingan Umum. Prosedur pengadaan tanah yang berkaitan

\footnotetext{
Boedi Harsono, 2005, Hukum Agraria Indonesia, Sejarah Pembentukan UndangUndang Pokok Agraria, Isi dan Pelaksanaannya, Djambatan, Jakarta, hlm. 18 .

Ibid., hlm. 7.

Faried Ali, Op. cit., hlm. 65

Zaidar, Dasar Filosofi Hukum Agraria Indonesia, Pustaka Bangsa Press, Medan, 2009, hlm. 166-167.

Pasal 1 angka 6 Undang-Undang Nomor 26 Tahun 2007 tentang Penataan Ruang (Lembaran Negara Republik Indonesia Tahun 2007 Nomor 68, Tambahan Lembaran Negara Republik Indonesia Nomor 4725).

3 Pasal 1 angka 11 Undang-Undang Nomor 26 Tahun 2007 tentang Penataan Ruang (Lembaran Negara Republik Indonesia Tahun 2007 Nomor 68, Tambahan Lembaran Negara Republik Indonesia Nomor 4725).
} 
erat dengan tugas administrasi pertanahan meliputi penetapan lokasi, persetujuan penetapan lokasi, pengajuan permohonan untuk memulai pelaksanaan pengadaan tanah kepada Panitia pengadaan Tanah, penetapan batas lokasi tanah, penerbitan Surat Keputusan Penetapan Harga oleh Panitia Pengadaan Tanah, pelepasan hak, permohonan hak atas tanah. ${ }^{14}$

\section{c. Pemeliharaan Tanah}

Ketentuan Pasal 15 UUPA menyatakan bahwa pemeliharaan tanah, termasuk kesuburannya serta mencegah kerusakannya adalah kewajiban tiap-tiap orang, badan hukum atau instansi yang mempunyai hubungan hukum dengan tanah itu. ${ }^{15}$ Ketentuan tersebut memberikan pengertian bahwa pemeliharaan tanah berkaitan dengan hubungan hukum dengan tanah, dengan kata lain pemeliharaan tanah juga menyangkut dengan pengaturan hak-hak atas tanah.

Aspek administrasi pertanahan dalam pengaturan hak-hak atas tanah adalah mengenai pendaftaran tanah. Menurut ketentuan Peraturan Pemerintah Nomor 24 Tahun 1997 dinyatakan bahwa yang terkait segi administratif disebutkan adalah data yuridis, sedangkan segi teknis adalah data fisik. Data yuridis maksudnya adalah keterangan mengenai status hukum bidang tanah dan satuan rumah susun yang didaftar, pemegang haknya dan hak pihak lain serta beban-beban lain yang membebaninya. ${ }^{16}$ Bila dinyatakan sebagai status hukum bidang tanah yang terdaftar, berarti terdapat bukti yang menunjukkan adanya hubungan hukum antara orang dengan tanahnya. Adanya bukti hubungan hukum tersebut kemudian diformalkan melalui kegiatan pendaftaran tanah. ${ }^{17}$

Kegiatan pendaftaran tanah yang memformalkan pemilikan tanah baik berdasarkan bukti-bukti pemilikan maupun penguasaan atas tanah selain menyangkut aspek yuridis dan aspek teknis, juga pelaksanaan pendaftaran tanah terkait dengan tugastugas keadministrasian. Dengan kata lain dalam kegiatan pendaftaran tanah terdapat tugas-tugas penatausahaan, seperti dalam hal penetapan hak atas tanah dan pendaftaran peralihan hak tanah. Bahkan dapat dikatakan bahwa kegiatan yang menyangkut aspek yuridis atau pengumpulan data yuridis sampai kepada penerbitan buku tanah, sertipikat dan daftar umum lainnya serta pencatatan perubahan di kemudian hari hampir seluruhnya menyangkut tugas-tugas administrasi. ${ }^{18}$

Berikut ini adalah pengaturan dari kegiatan administrasi dalam hal pendaftaran tanah yaitu sebagai berikut: ${ }^{19}$

1) Kegiatan pendaftaran tanah sebelum penerbitan sertipikat tanah berupa penetapan hak atas tanah dalam rangka kegiatan administrasi pendaftaran tanah tersebut dapat diperinci lagi, yakni Konversi hak atas tanah, Pengakuan dan penegasan hak atas tanah, Pemberian Hak Atas Tanah, Penolakan hak atas tanah, Redistribusi Tanah dan Konsolidasi tanah, Perwakafan Tanah

2) Kegiatan yang bersifat administratif setelah penerbitan

\footnotetext{
M. Yamin Lubis dan Abd. Rahim Lubis, 2011, Pencabutan Hak, Pembebasan, dan Pengadaan Tanah, Mandar Maju, Bandung, hlm. 66-95. Pasal 15 Undang-Undang Nomor 5 Tahun 1960 tentang Peraturan Dasar Pokok-Pokok Agraria (Lembaran Negara Republik Indonesia Tahun 1960 Nomor 104, Tambahan Lembaran Negara Republik Indonesia Nomor 2043).

16 Pasal 1 angka 6 Peraturan Pemerintah Nomor 24 Tahun 1997 tentang Pendaftaran Tanah (Lembaran Negara Republik Indonesia Tahun 1997 Nomor 59, Tambahan Lembaran Negara Republik Indonesia Nomor 3696).

M. Yamin Lubis dan Abd. Rahim Lubis, Ibid., hlm. 208.

Ibid., hlm. 208-209.

Ibid., hlm. 210-211.
} 
sertifikat tanah yang dilakukan

karena terjadinya perubahan data yuridis (subjek hak, jenis hak, dan jangka waktu hak atas tanahnya), terdiri dari Peralihan Hak Atas Tanah, Pemindahan Hak Atas Tanah, Perpanjangan Jangka Waktu Hak Atas Tanah, Pembaharuan Hak Atas Tanah, Perubahan Hak Atas Tanah, Pembatalan hak atas tanah, Pencabutan Hak atas tanah, Pembebanan Hak atas Tanah, Perubahan Data Karena Putusan dan Penetapan Pengadilan, Perubahan Data karena Perubahan Nama, Hapusnya Hak atas Tanah, Penggantian Sertipikat.

3) Kegiatan yang bersifat administratif setelah penerbitan sertipikat tanah yang dilakukan karena terjadinya perubahan data fisik atau obyek hak atas tanahnya, terdiri dari Pemecahan Bidang Tanah, Pemisahan Bidang Tanah, dan Penggabungan Bidang Tanah.

Sebagai negara yang berdasar pada hukum, dalam kaitannya dengan penerbitan sertifikat hak atas tanah, pemerintah harus dapat memberikan kepastian hukum. Kepastian hukum dapat terwujud apabila tindakan pemerintah dilakukan secara akuntabel. Berdasarkan konsep good governance, maka penyelenggaraan kekuasaan pemerintahan harus didasarkan pada tata kelola pemerintahan yang baik. ${ }^{20}$

Hukum harus mencerminkan asas prosedural (fairness), keterbukaan sistem (transparency), keterbukaan hasilkerja(disclausure), pertanggungan jawab publik (accountability), dan kewajiban keterbukaan kepada masyarakat (responsibility). Prinsip-prinsip yang tertuang dalam konsep good governance harus sejalan dengan konsep Asas-Asas Umum Pemerintahan yang Baik (AAUPB). Good governance sebagai norma pemerintahan adalah

20 Patut diingat bahwa kata governance memiliki pemaknaan yang berbeda dengan government. Dari aspek subjek yang terlibat, maka kata government merupakan suatu kata yang menunjuk pada suatu organisasi pengelolaan berdasarkan kekuasaan tertinggi (negara dan pemerintah), sedangkan kata governance melibatkan tidak sekedar pemerintah, tetapi juga peran berbagai aktor di luar pemerintah, sehingga pihak-pihak yang terlibat juga sangat luas. Perbedaan pengertian tersebut berkonsekuensi pada penggunaan kata tersebut dalam konteksnya. Dalam konteks negara hukum, governance diarahkan pada suatu penyelenggaraan pemerintahan yang berdasarkan konstitusi dan melibatkan aktor-aktor yang secara normatif sebagaimana diatur dalam peraturan perundang-undangan. Pinto dan Nisjar mengemukakan bahwa governance adalah praktik penyelenggaraan kekuasaan kewenangan oleh pemerintah dalam pengelolaan urusan pemerintahan secara umum dan pembangunan ekonomi secara khususnya. Dengan demikian, pengertian governance adalah proses penyelenggaraan kekuasaan negara terkait dengan penyediaan pelayanan publik. Lihat dalam Philipus M. Hadjon, et al., 2010, Hukum Administrasi dan Good Governance, Universitas Trisakti, Jakarta, hlm. 4. Menurut UNDP (United Nation Development Program), terdapat 9 (sembilan) karakteristik good governance, yaitu (1) Partisipasi(Participation): setiap orang atau setiap warga masyarakat, memiliki hak suara yang sama dalam proses pengambilan keputusan, baik secara langsung maupun melalui lembaga perwakilan, sesuai dengan kepentingan dan aspirasinya masing-masing. Partisipasi yang luas ini perlu dibangun dalam suatu tatanan kebebasan berserikat dan berpendapat, serta kebebasan untuk berpartisiapsi secara konstruktif. (2) Aturan Hukum(Rule of Low): kerangka aturan hukum dan perundang-undangan haruslah berkeadilan, ditegakkan, dan dipatuhi secara utuh (impartially), terutama aturan hukum tentang Hak-hak asasi manusia. (3) Transparansi(Transparency): Transparansi harus dibangun dalam kerangka kebebasan aliran informasi. Berbagai proses, kelembagaan, dan informasi harus dapat diakses secara bebas oleh mereka yang membutuhkannya, dari informasinya harus dapat disediakan secara memadai dan mudah dimengerti, sehingga dapat digunakan sebagai alat monitoring dan evaluasi. (4) Daya tanggap(Responsiveness): setiap institusi dan prosesnya harus diarahkan pada upaya untuk melayani berbagai pihak yang berkepentingan (Stakeholders);(5) Berorientasi Konsensus(Consensus Orientation): pemerintahan yang baik (good governance) akan bertindak sebagai penengah (mediator) bagi berbagai kepentingan yang berbeda untuk mencapai konsensus atau kesepakatan yang terbaik bagi kepentingan masing-masing pihak, dan jika dimungkinkan juga dapat diberlakukan terhadap berbagai kebijakan dan prosedur yang akan ditetapkan pemerintah;(6) Berkeadilan(Equity): pemerintahan yang baik akan memberikan kesempatan yang sama baik terhadap laki-laki maupun perempuan dalam upaya mereka untuk meningkatkan dan memelihara kualitas hidupnya; (7) Efektivitas dan Efesiensi(Effectiveness and Efficiency): setiap proses kegiatan dan kelembagaan diarahkan untuk menghasilkan sesuatu yang benar-benar sesuai dengan kebutuhan melalui pemanfaatan yang sebaik-baiknya berbagai sumber-sumber yang tersedia; (8) Akuntabilitas(Accountabilty): para pengambil keputusan (decision makers) dalam organisasi sector public (pemerintah), swasta, Dan masyarakat madani memiliki pertanggungjawaban (akuntabilitas) kepada publik (masyarakat umum), sebagaimana halnya kepada para pemilik (stakeholders). Pertanggungjawaban tersebut berbeda-beda, tergantung apakah jenis keputusan organisasi itu bersifat internal atau bersifat eksternal; (9) Bervisi Strategis(Strategic Vision): para pemimpin dan masyarakat memiliki persepktif yang luas dan jangka panjang tentang penyelenggaraan pemerintahan yang baik (good governance) dan pembangunan manusia (human development). Bersamaan dengan dirasakannya kebutuhan untuk pembangunan tersebut. Mereka juga memahami aspek-aspek histori, cultural, dan kompleksitas yang mendasari perspektif mereka. Lihat dalam Riant Nugroho D., 2003, Kebijakan Publik: Formulasi, Implementasi dan Evaluasi, Elex Media Komputindo, Jakarta, hlm. 219-220. 
suatu sasaran yang akan dituju dan diwujudkan dalam pelaksanaan pemerintahan yang baik dan AAUPB sebagai norma mengikat yang menuntun pemerintah dalam mewujudkan good governance. Sinergitas antara good governance dengan AAUPB dapat mencerminkan pemerintahan yang bersih dan berwibawa. Prinsip-prisip AAUPB tertuang dalam Pasal 3 Undang-Undang Nomor 28 Tahun 1999 tentang Penyelenggaraan Negara yang Bersih dan Bebas dari Korupsi, Kolusi dan Nepotisme, yaitu Asas Kepastian Hukum, Asas Tertib Penyelenggaraan Negara, Asas Kepentingan Umum, Asas Keterbukaan, Asas Proporsionalitas, Asas Profesionalisme, dan Asas Akuntabilitas. ${ }^{21}$

Sehubungan dengan administrasi pertanahan, dalam pendaftaran tanah dikenal Asas Publisitas ${ }^{22}$ yang menyebut semua orang boleh memperoleh informasi mengenai tanah yang didaftar. Informasi ini menyangkut prinsip yaitu:

1. Transparansi,merupakan

suatu

keadaan dimana setiap orang berhak mengetahui setiap proses pembuatan dan pengambilan keputusan yang dilakukan didalam pemerintahan yang berdampak langsung maupun tidak langsung kepada masyarakat, wajib mengikutkan dan melibatkan atau memberi kesempatan kepada masyarakat untuk secara terbuka menyampaikan aspirasinya.

2. Keterbukaan,adalah sikap mental membuka diri terhadap hak masyarakat untuk memperoleh informasi yang benar, jujur dan tidak diskriminatif tentang penyelenggaraan pemerintahhan dengan tetap memperhatikan perlindungan atas hak asasi pribadi, golongan dan rahasia Negara dan keterbukaan ini mendukung pelaksanaan pemerintahan yang transparan, yang bersedia untuk memberikan informasi yang benar dan terbuka terhadap masukan atau permintaan orang lain. ${ }^{23}$

Transparansi dalam pendaftaran tanah merupakan hal terpenting yang harus dilaksanakan dalam hal pendaftaran atas tanah yang dilaksanakan oleh pihak Kantor Pertanahan agar prosedur pengurusan dan pelayanan berjalan seperti yang diharapkan oleh masyarakat khususnya pemohon yang akan melakukan pendaftaran atas tanah yang meliputi proses pemeriksaan kelengkapan atas dokumen-dokumen yang diperlukan untuk suatu pendaftaran atas tanah. Dengan dilakukannya prinsip transparansi secara berkesinambungan, maka diharapkan informasi yang berkaitan dengan proses hingga penerbitan sertifikat dapat diakses oleh semua pihak sehingga apabila ada informasi yang dianggap keliru segera dapat dilakukan perbaikan oleh Kantor Pertanahan. Terang saja bahwa masalah yang berkaitan tentang sertifikat sudah cukup kompleks, misalnya terjadinya sertifikat ganda. Seyogyanya atas objek yang sama, maka sertifikat yang dikeluarkan tidak mungkin ada dua sebab proses hingga terjadi penerbitan

21 Muin Fahmal, 2008, Peran Asas-Asas Umum Pemerintahan yang Layak dalam Mewujudkan Pemerintahan yang Bersih, Kreasi Total Media, Yogyakarta, hlm. 94. Penjelasan Asas-Asas Umum Pemerintahan Yang Baik adalah (1) Asas kepastian hukum yaitu asas yang megutamakan landasan peraturan perundang-undangan, kepatutan dan keadilan dalam setiap kebijakan penyelenggara negara; (2) Asas tertib penyelenggaraan negara yaitu asas yang menjadi landasan keteraturan, keserasian, dan keseimbangan dalam pengendalian penyelenggara negara; (3) Asas kepentingan umum yaitu asas yang mendahulukan kesejahteraan umum dengan cara yang aspiratif, akomodatif, dan selektif; (4) Asas keterbukaan yaitu asas yang membuka diri terhadap hak masyarakat untuk memperoleh informasi yang benar, jujur dan tidak diskriminatif tentang penyelenggaraan negara dengan tetap memperhatikan perlindungan atas hak asasi pribadi, golongan dan rahasia negara; (5) Asas proporsionalitas adalah asas yang mengutamakan keseimbangan antara hak dan kewajiban penyelenggara negara; (6) Asas profesionalitas yaitu asas yang mengutamakan keadilan yang berlandaskan kode etik dan ketentuan peraturan perundang-undangan yang berlaku; (7) Asas akuntabilitas adalah asas yang menentukan, bahwa setiap kegiatan dan hasil akhir dari kegiatan penyeelenggara negara harus dapat dipertanggungjawabkan kepada masyarakat atau rakyat sebagai pemegang kedaulatan tertinggi negara sesuai dengan ketentuan peraturan perundang-undangan yang berlaku.

22 Menurut Sudikno Mertukusumo, ada 2 (dua) asas Pendaftaran Tanah, yaitu Asas Specialiteit dan Asas Openbaarheid (asas publisitas). Asas Specialiteit berarti pelaksanaan pendaftaran tanah diselenggarakan atas dasar peraturan perundang-undangan tertentu yang secara teknis menyangkut masalah pengukuran, pemetaan, dan pendaftaran peralihannya. Sedangkan Asas Openbaarheid (Asas Publisitas) berarti setiap orang berhak untuk mengetahui data yuridis tentang subjek hak, nama hak atas tanah, peralihan hak, dan pembebanan hak atas tanah yang ada di Kantor Pertanahan termasuk mengajukan keberatan sebelum diterbitkannya sertifikat, sertifikat pengganti, sertifikat yang hilang atau sertifikat yang rusak. Lihat dalam Urip Santoso, 2010, Pendaftaran dan Peralihan Hak Atas Tanah, Kencana, Jakarta, hlm. 14-16.

23 Meiji Morico, 2007, Prinsip Transparansi dalam Pendaftaran Tanah di Kantor Pertanahan Kota Medan, Tesis, Fakultas Hukum Universitas Sumatera Utara, Medan, hlm. 64-67. 
sertifikat harus menekankan asas transparansi agar terjadi cross check yang akurat dengan masyarakat setempat atau dengan seluruh pihak yang berkepentingan. Namun pengabaian prinsip transparansi inilah yang kemudian mengakibatkan terjadinya permasalahan mengenai sertifikat ganda. Di sisi lain, sertifikat merupakan alat bukti yang kuat untuk menunjukkan status kepemilikan/hak seseorang pada tanah sehingga keberadaannya menjadi surat yang berharga dan sangat penting.

Selain itu, pengutamaan prinsip responsif sebagai salah satu prinsip yang tertuang dalam konsep good governance juga harus dilakukan. Salah satu asas fundamental menuju cita-cita Good Governance adalah responsif, yakni pemerintahan harus peka dan cepat tanggap terhadap persoalanpersoalan masyarakat. Terkait dengan asas responsif ini, pemerintah harus merumuskan kebijakankebijakan pembangunan sosial terhadap semua kelompok sosial dalam karakteristik kulturalnya. Dalam upaya mewujudkan asas responsif pemerintah harus melakukan upaya-upaya strategis dalam memberikan perlakuan yang humanis pada kelompok-kelompok masyarakat tanpa pandang bulu. Pemerintah tidak boleh bersifat pasif melainkan harus responsif terhadap masyarakat dalam seluruh aspek, termasuk dalam pelayanan di bidang pertanahan. Prinsip responsif menekankan bahwa setiap institusi dan prosesnya harus diarahkan pada upaya untuk melayani berbagai pihak yang berkepentingan. Dikhawatirkan sikap pasif pemerintah atau kurang tanggapnya pemerintah dalam pelayanan termasuk dalam administrasi pemerintahan akan menimbulkan pelayanan pertanahan yang tidak mampu memenuhi kebutuhan masyarakat.

Sesuai dengan asas responsif, maka setiap unsur pemerintah harus memiliki dua etika, yakni etika individual dan sosial. Kualifikasi etika individual menuntut pelaksana birokrasi pemerintah agar memiliki kriteria kapabilitas dan layolitas profesional. Adapun etika sosial menuntut mereka agar memiliki sensitivitas terhadap berbagai kebutuhan publik. $^{24}$ Perwujudan good governance secara langsung dapat kita jumpai pada pelaksanaan pelayanan publik. Ada beberapa alasan mengapa pelayanan publik menjadi titik strategis untuk memulai pengembangan dan penerapan good governance di Indonesia, yaitu: ${ }^{25}$

1. Pelayanan publik selama ini menjadi area di mana negara yang diwakili pemerintah berinteraksi dengan lembaga non-pemerintah. Keberhasilan dalam pelayanan publik akan mendorong tingginya dukungan masyarakat terhadap kerja birokrasi.

2. Pelayanan publik adalah wilayah di mana berbagai aspek good and clean governance bisa diartikulasikan secara lebih mudah.

3. Pelayanan publik melibatkan kepentingan semua unsur governance, yaitu pemerintah, maysarakat, dan mekanisme pasar.

Oleh karena itu, dalam pelayanan publik yang dilakukan oleh pemerintah, termasuk dalam bidang pertanahan, secara responsif pemerintah harus mampu menanggapi keluhan, tuntutan, dan memenuhi kebutuhan masyarakat sehingga proses pelayanan terhadap penerbitan sertifikat bisa dilakukan dengan baik dan akuntabel. Kegunaan penerapan prinsip transparansi dan responsif dalam pelayanan publik diharapkan akan melahirkan tindakan pemerintah yang akuntabel, yaitu tindakan yang dapat dipertanggungjawabkan kepada publik. Dengan demikian, akuntabilitas pemerintah dalam menerbitkan sertifikat hak atas tanah dapat terwujud sebab telah dilakukan secara transparan dan dengan mengutamakan daya tanggap yang kuat terhadap setiap orang yang berkepentingan. Berdasarkan uraian konsep yang telah dijelaskan, maka prinsip transparansi, responsif, dan akuntabilitas dalam administrasi pemerintahan khususnya pada kegiatan

\footnotetext{
24 Yona Ramadhani, “Tata Kelola Pemerintahan yang Baik dan Bersih (Good and Clean Governance),"https://www.academia.edu/9966363/ BAB 9 Tata Kelola Pemerintahan yang Baik dan Bersih good and clean governance ?auto=download, diakses pada tanggal 28 September 2016 
penerbitan sertifikat, secara normatif dapat ditinjau terlebih dahulu berdasarkan standar operasional prosedur yang dimiliki oleh Kantor Pertanahan.

Secara faktual, salah satu faktor yang menyebabkan timbulnya sengketa tanah di masyarakat disebabkan sikap yang sedemikian pasif dari Kantor Pertanahan yang dalam proses pendaftaran tanah hanya menerima berkas yang diajukan oleh pemohon. Dengan demikian, dapat dikatakan bahwa tidak ada upaya dari pihak Kantor Pertanahan untuk mencari tahu apakah bidang tanah yang dimohonkan pendaftarannya terdapat sengketa atau memiliki potensi sengketa di atasnya sehingga seakan-akan tidak ada kepastian hukum dalam pendaftaran tanah.

Kurangnya transparansi dalam hal penguasaan dan pemilikan tanah disebabkan oleh terbatasnya data serta informasi penguasaan dan pemilikan tanah. Sebagai dampak lanjutannya, hal ini dapat menjadi salah satu penyebab timbulnya sengketa-sengketa tanah. Selain itu, hal ini akan menyebabkan terkonsentrasinya penguasaan dan pemilikan tanah dalam hal luasan di pedesaan dan/atau jumlah bidang tanah di perkotaan, hanya pada sebagian kecil masyarakat. Di sisi lain penyertifikatan tanah tampaknya masih cenderung kepada akses permintaan yang jauh melampaui sisi penawaran meskipun proyek-proyek administrasi pertanahan seperti prona dan proyek adjukasi relatif berhasil mencapai tujuannya.

Kesalahan yang kerap dilakukan oleh petugas pertanahan dan minimnya akses informasi pertanahan diharapkan dapat diminimalisir dengan adanya penertiban administrasi pertanahan melalui sistem elektronik dalam penggunaan komputer, sebagaimana diatur dalam Keputusan Presiden Nomor 34 Tahun 2003 tentang Kebijakan Nasional di Bidang Pertanahan yang mana pada Pasal 1 huruf $\mathrm{b}$ menugaskan kepada Badan Pertanahan Nasional untuk melakukan pembangunan sistem informasi pertanahan dan manajemen pertanahan yang meliputi penyiapan aplikasi data tekstual dan spasial dalam pelayanan pendaftaran tanah dan penyusunan basis data penguasaan dan pemilikan tanah yang dihubungkan e-government, e-commerce dan e-payment. ${ }^{26}$

Badan Pertanahan Nasional sebagaimana dalam Pasal 1 huruf b Keputusan Presiden Nomor 34 Tahun 2003 tentang Kebijakan Nasional Badan Pertanahan, ditugaskan untuk membangun dan mengembangkan Sistem Informasi Pertanahan dan Manajemen Pertanahan Nasional (SIMTANAS) yang meliputi: ${ }^{27}$

1. Penyusunan basis data tanah-tanah asset negara pemerintah/ pemerintah daerah di seluruh Indonesia. Kegiatan ini meliputi:

a. Inventarisasi aset Negara, Pemerintah, Pemerintah Daerah dan Perwakilan Negara Asing.

b. Pembangunan Database Asset yang memuat informasi penguasaan, pemilikan, penggunaan dan pemanfaatan tanah, alamat persil, identitas bidang, luas, jenis hak, NOP, NJOP, IMB, foto bangunan, perubahan data pemilikan.

2. Pemetaan kadastral dalam rangka inventarisasi dan registrasi penguasaan, pemilikan, penggunaan dan pemanfaatan tanah (P4T) dengan menggunakan teknologi citra satelit dan teknologi informasi untuk menunjang kebijakan pelaksanaan landreform dan pemberian hak atas tanah. Kegiatan ini berupa Pemetaan Kadastral Digital dengan menggunakan teknologi Pemotretan Udara dan Citra Satelit, dengan cakupan data:

a. Titik ground control dengan menggunakan Global Positioning System (GPS)

b. Peta pendaftaran yang memuat informasi bidang-bidang tanah dan nomor identifikasinya.

\footnotetext{
Pasal 1 huruf b Keputusan Presiden Nomor 34 Tahun 2003 tentang Kebijakan Nasional di Bidang Pertanahan.

27 Pasal 1 huruf b Keputusan Presiden Nomor 34 Tahun 2003 tentang Kebijakan Nasional Badan Pertanahan, ditugaskan untuk membangun dan mengembangkan Sistem Informasi Pertanahan dan Manajemen Pertanahan Nasional (SIMTANAS) lebih lajut lihat Adrian Sutedi, 2009,
} Tinjauan Hukum Pertanahan, Pradnya Paramita, Jakarta, hal. 24. 
c. Batas administrasi pemerintah (Desa/ Kelurahan, Kecamatan, Kabupaten/ Kota).

d. Batas kawasan penggunaan tanah (industri, perumahan, perkebunan, kehutanan, persawahan). Peta kadastral tersebut dapat memberikan manfaat untuk kegiatan inventarisasi dan registrasi, perencanaan dan implementasi kebijakan nasional di bidang landreform, percepatan pemberian Hak Atas Tanah dan pembebasan tanah untuk kepentingan umum dan masyarakat, dan mendukung terciptanya Sistem Informasi Pertanahan Nasional berbasis tanah (multipurpose kadastral).

3. Pembangunan dan pengembangan pengelolaan penggunaan dan pemanfaatan tanah melalui system informasi geografi, dengan mengutamakan penetapan zona sawah beririgasi dan tanah-tanah produktif lainnya, dalam rangka memelihara ketahanan pangan nasional.

Hal ini juga tentunya sesuai dengan UndangUndang Nomor 14 Tahun 2008 tentang Keterbukaan Informasi Publik yang mengatakan bahwa informasi merupakan kebutuhan pokok setiap orang bagi pengembangan pribadi dan lingkungan sosialnya serta merupakan bagian penting bagi ketahanan nasional. ${ }^{28}$ Terkait dengan hal ini, telah diterbitkan Peraturan Kepala Badan Pertanahan Nasional RI Nomor 6 Tahun 2013 tentang Pelayanan Informasi Publik di Lingkungan Badan Pertanahan Nasional Republik Indonesia yang isinya menyatakan bahwa peraturan Kepala Badan Pertanahan Nasional RI ini sebagai tindak lanjut dari Pasal 7 ayat (3) Undang-Undang Nomor 14 Tahun 2008 tentang Keterbukaan Informasi Publik. ${ }^{29}$ Peraturan Kepala Badan Pertanahan Nasional RI ini ditujukan dalam rangka menjalankan kewajiban menyediakan Informasi Publik yang akurat, benar, dan tidak menyesatkan. Oleh karena itu, setiap Badan Publik harus membangun dan mengembangkan sistem informasi dan dokumentasi untuk mengelola informasi publik secara baik dan efisien sehingga dapat diakses dengan mudah oleh setiap orang.

Pada implementasinya kemudian, kebijakan SIMTANAS ini harus direalisasikan dalam bentuk bank data kegiatan pertanahan yang terpusat dan berbasis komputerisasi. SIMTANAS dalam implementasinya adalah Komputerisasi Kegiatan Pertanahan (KKP). KKP ini adalah segala kegiatan pertanahan yang berbaris komputerisasi atau dengan kata lain tidak ada lagi kegiatan manual, mulai dari awal pendaftaran hingga terbitnya sertifikat atau berita acara.

Cikal bakal KKP sebenarnya merupakan program yang telah dioperasikan di Kantor Pertanahan sejak Tahun 1997 yang biasanya disebut dengan Land Office Computerization (LOC). Sejak Tahun 1999 Badan Pertanahan Nasional Republik Indonesia (BPN RI) telah mulai melakukan pembangunan database pertanahan secara elektronik melalui kegiatan KKP/LOC untuk menjamin bahwa data pertanahan elektronik menjadi informasi yang terkini dengan menggunakan aplikasi pelayanan pertanahan yang tersedia dengan peralatan teknologi.

Sebagai contoh, beberapa layanan informasi telah disiapkan dalam website BPN melalui laman http://www.bpn.go.id seperti peta online dan informasi status berkas permohonan. Layananlayanan lainnya yang sedang disiapkan adalah layanan PPAT untuk pengecekan sertifikat dan untuk pendaftaran pelayanan secara online serta layanan e-form sebagai sarana pengisian form pendaftaran pertanahan secara online. Mulai Tahun 2008 juga sedang dibangun pusat data di BPN Pusat untuk membangun database pertanahan secara nasional dan sebagai backup data untuk semua Kantor Pertanahan menggunakan teknologi komputer.

28 Lihat dalam Konsideran "Menimbang" poin a Undang-Undang Nomor 14 Tahun 2008 tentang Keterbukaan Informasi Publik (Lembaran Negara Republik Indonesia Tahun 2008 Nomor 3696, Tambahan Lembaran Negara Republik Indonesia Nomor 4846).

29 Pasal 7 ayat (3) Undang-Undang Nomor 14 Tahun 2008 tentang Keterbukaan Informasi Publik mengatur bahwa "Untuk melaksanakan kewaj iban sebagaimana dimaksud pada ayat (2), Badan Publik harus membangun dan mengembangkan sistem informasi dan dokumentasi untuk mengelola Informasi Publik secara baik dan efisien sehingga dapat diakses dengan mudah." 
Informasi yang terdapat dalam KKP hampir sama dengan data yang didapati pada sistem manual. Sumber datanya pun sama, yakni didapatkan secara manual. Perbedaannya hanyalah pada sistem penyimpanan yang memanfaatkan komputer sehingga tidak memerlukan banyak tempat penyimpanan. Data yang tersimpan dalam aplikasi KKP web ini merupakan data yang diperoleh dan diolah melalui proses yang rumit dan panjang mengikuti aturan yang tertuang pada Peraturan Kepala BPN RI Nomor 1 Tahun 2005 tentang Standar Prosedur Opersional Pelayanan Pertanahan (SPOPP). Pembaruan data selalu dilakukan apabila terjadi perubahan pada subjek atau obyek hak atas tanah karena sifatnya yang sangat dinamis. maka data pertanahan mempunyai tingkat pengambilan (retrievel) dan pembaruan (up dated) yang cukup tinggi. Di satu sisi membutuhkan kecepatan dengan standar yang sudah ditetapkan dalam mengambil data, sedangkan di sisi lain akan membutuhkan persyaratan dalam penyimpanan data (storage) yang dapat mendukung proses pengambilan data tersebut.

KKP Web ini berisi data tekstual dan data spasial mengenai kepemilikan dan penguasaan suatu bidang tanah yang telah terdaftar di Kota Makassar. Data tekstual tanah yang telah terdaftar, kemudian dikonversi ke dalam data elektronik yang disajikan dalam aplikasi tersebut. Dengan demikian, penyiapan data yang terdapat dalam aplikasi KKP Web itu diperoleh dari, antara lain:

1. Buku Tanah, yakni dokumen dalam bentuk daftar yang memuat data yuridis suatu objek pendaftaran tanah yang sudah ada haknya. ${ }^{30}$ Dokumen ini menegaskan data keabsahan penguasaan/kepemilikan hak pemegang sertifikat dan data keabsahan obyektif bidang tanah yang dikuasai/dimiliki oleh pemegang sertifikat.

2. Gambar Situasi/Surat Ukur, yakni dokumen yang memuat data fisik suatu bidang tanah dalam bentuk peta dan uraian ${ }^{31}$. Dokumen ini menyatakan kepastian lokasi dan besaran-besaran obyektif (lokasi, batas dan luas) dari bidang tanah yang digambarkan yang dikuasai/dimiliki oleh pemegang sertifikat. Surat Ukur pada sertifikat hak milik atas tanah merupakan hasil salinan dari Peta Pendaftaran Tanah (biasanya pada cara pendaftaran tanah sistematik) atau dari hasil pengukuran bidang tanah (biasanya pada cara pendaftaran tanah sporadik). Surat Ukur berisi dua jenis data. Pertama, data berupa uraian mengenai Nomor Surat Ukur, lokasi (Desa/Kelurahan, Kabupaten/Kota, dan Propinsi); Nomor Peta Pendaftaran (yang menjadi sumber kutipan Surat Ukur), keadaan tanah, tanda-tanda batas, luas bidang tanah, penunjukan dan penetapan batas, pengesahan Kepala Kantor Pertanahan atau Ketua Panitia Ajudikasi atas nama Kepala Kantor Pertanahan dan keterangan pemisahan/ pengggabungan/penggantian sertifikat. Kedua, peta bidang tanah (lengkap dengan penunjuk arah Utara sebagai orientasi) yang disertifikatkan dan bidang-bidang tanah lain sekitarnya yang berbatasan, yang dibubuhi nomornomor bidang tanah (dalam lima digit) dalam wilayah Desa/Kelurahan lokasi bidang tanah bersangkutan.Peta Pendaftaran. Peta pendaftaran adalah peta yang menggambarkan bidang atau bidang-bidang tanah untuk keperluan pembukuan tanah. Peta Pendaftaran merupakan peta tematik, yakni peta yang menginformasikan mengenai bentuk, batas, letak, nomor bidang dari setiap bidang tanah dan digunakan untuk keperluan pembukuan bidang. ${ }^{32}$

Ketiga sumber data pertanahan di atas seharusnya dapat memastikan aplikasi KKP web yang digunakan oleh Kantor Pertanahan menghimpun segala informasi mengenai bidang-

\footnotetext{
$30 \quad$ Pasal 1 butir 19 Peraturan Pemerintah Nomor 24 Tahun 1997 tentang Pendaftaran Tanah (Lembaran Negara Republik Indonesia Tahun 1997 Nomor 59, Tambahan Lembaran Negara Republik Indonesia Nomor 3696).

31 Pasal 1 butir 17 Peraturan Pemerintah Nomor 24 Tahun 1997 tentang Pendaftaran Tanah (Lembaran Negara Republik Indonesia Tahun 1997 Nomor 59, Tambahan Lembaran Negara Republik Indonesia Nomor 3696).
} 
bidang tanah di suatu wilayah. Informasi mengenai pemilik suatu bidang tanah, luas bidang tanah, lokasi, hingga batas bidang tanah yang dikuasai oleh pemegang sertifikat terangkum dalam aplikasi tersebut. Aplikasi KKP web inijuga menggambarkan peta seluruh bidang tanah. Gambaran mengenai bentuk, batas, letak, nomor bidang dari setiap bidang tanah dapat dilihat dalam aplikasi yang telah dijalankan oleh Kantor Pertanahan.

Penyiapan data elektronik dalam aplikasi KKP web ini dimulai dengan menghimpun semua data pertanahan yang telah terdaftar di Kantor Pertanahan. Data pertanahan itu diambil berdasarkan buku tanah, gambar situasi/surat, dan peta pendaftaran suatu bidang tanah yang didaftarkan oleh masyarakat. Seluruh data pertanahan yang masuk dihimpun dan kemudian dikelola oleh kantor Pertanahan tingkat kota/kabupaten.

Data yang masuk terdiri dari dua jenis, yakni data tekstual dan data grafik. Data diklasifikasikan berdasarkan jenis yang dihimpun dan dikelola oleh Kantor Pertanahan tingkat kota/kabupaten. Data pertanahan yang terhimpun kemudian dimasukkan ke dalam basis data milik kantor pertanahan di tingkat provinsi di wilayah tersebut. Aktivitas penghimpunan data ini dilakukan di setiap proses pendaftaran tanah pada kantor pertanahan tingkat kabupaten/kota di setiap harinya. Dengan begitu, data yang diperoleh dari setiap pendaftaran tanah langsung terhimpun dalam basis data milik kantor pertanahan provinsi.

Secara ideal penerapan Sistem Informasi dan Manajemen Pertanahan Nasional (SIMTANAS) melalui aplikasi KKP web memiliki keunggulan, yakni:

1. Transparansi pelayanan terhadap masyarakat dimana masyarakat dapat memperoleh informasi secara langsung dalam hal biaya, waktu pelaksanaan dan kepastian penyelesaian pendaftaran tanah.

2. Efesiensi waktu dimana prinsip one captured multi used merupakan kunci utama dalam optimalisasi pemanfaatan database elektronik.

3. Kualitas data yang berada dalam aplikasi yang digunakan dapat diandalkan sebab pemberian nomor-nomor daftar isian dilakukan oleh sistem secara otomatis.

4. Sistem informasi eksekutif memungkinkan para pengambil keputusan untuk dapat memperoleh dan menganalisa data sehingga menghasilkan informasi yang terintegrasi.

5. SIMTANAS mendukung adanya pertukaran data dalam rangka membangun pelayanan pemerintah secara terpadu (one stop services) dan mengembangkan perencanaan pembangunan berbasis data spasial (spatial planning).

Diberlakukannya kebijakan SIMTANAS ini diharapkan membawa angin segar terhadap proses pelayanan publik di lingkup Kantor Pertanahan Kota Makassar. Proses pendaftaran tanah yang selama ini memakan biaya, waktu, tenaga dan prosedur yang berbelit diharapkan bisa menjadi lebih mudah dan efisien sehingga SIMTANAS dapat membantu memudahkan masyarakat dalam proses mendapatkan informasi dari sisi waktu, biaya, tenaga, dan prosedur. Di samping itu, SIMTANAS juga turut membantu pejabat struktural dalam memperoleh informasi tentang kinerja kantor berupa laporan secara cepat, akurat, dan aktual karena dikerjakan oleh sistem (bukan SDM) dan membangun kedisiplinan seluruh pegawai untuk memelihara dan konsisten terhadap aplikasi KKP web yang sudah dibangun BPN pusat sehingga kualitas informasi pada SIMTANAS terjaga tetap cepat, akurat, dan aktual.

Kondisi ideal yang dicita-citakan dengan penerapan SIMTANAS sebagaimana dipaparkan di atas masih berbanding terbalik dengan yang terjadi secara faktual di lapangan, khususnya di Kota Makassar. SIMTANAS diarahkan untuk 32. Hal ini sesuai dengan Pasal 1 angka (15) Peraturan Pemerintah Nomor 24 Tahun 1997 tentang Pendaftaran Tanah dan Pasal 141 PMNA/KBPN
Nomor 3 Tahun 1997. 
dapat memberikan pelayanan secara efektif dan efisien kepada masyarakat, khususnya dalam hal kemudahan dalam memberikan informasi pertanahan. Namun yang terjadi adalah masih banyak data pertanahan dalam suatu wilayah yang tidak ter-up date di KKP Web sehingga masyarakat masih terbatas mengakses data-data yang diinginkannya mengenai suatu bidang tanah. Bukan hanya hal tersebut, terkait dengan administrasi pertanahan lainnya seperti pendaftaran tanah secara on line juga belum diterapkan, khususnya di Kantor Pertanahan Kota Makassar.

Secara ideal, KKP Web dapat menjamin efektifitas danefisiensipenyelenggaraanadministrasi pertanahan di setiap Kantor Pertanahan. Selain membantu masyarakat untuk mengakses informasi yang komprehensif mengenai kegiatan pertanahan, keberadaan sistem informasi sangat penting untuk mendukung BPN dalam melaksanakan tugasnya. BPN nampaknya menyadari bahwa unit organisasi yang ingin berhasil, memerlukan sistem manajemen informasi dalam melaksanakan tugas. Kriteria tugas yang pasti akan mendorong pencapaian tugas secara tepat sehingga berfungsi dalam pengambilan keputusan.

Penerapan SIMTANAS masih memiliki kelemahan di beberapa aspek. Hal ini dikarenakan pada prakteknya kegiatan pendaftaran tanah masih dominan dilaksanakan secara manual kendati sistem ini telah diberlakukan. Perlu diketahui bahwa sejak BPN berdiri hingga Tahun 1997, segala kegiatan di BPN dan Kantor Pertanahan dilaksanakan secara manual. Baru pada Tahun 1997 dioperasikan program Land Office Computerization (LOC) yang efektif berlaku sejak Tahun 1999. Pengoperasionalan LOC sesungguhnya belum optimal karena secara faktual kegiatan di Kantor Pertanahan masih dijalankan secara manual sehingga data yang ada di LOC tidak ter-update. Hal ini menjadi kendala tersediri dalam upaya mengintegrasikannya ke dalam SIMTANAS oleh karena pihak Kantor Pertanahan harus menyiapkan segala data yang ada yang diambil secara manual sejak dahulu hingga sekarang untuk di-update ke dalam KKP Web.

Pihak Kantor Pertanahan harus secara aktif melengkapi data pertanahan yang ada di wilayah kerjanya untuk menerapkan secara optimal KKP Web ini. Misalnya Kantor Pertanahan Kota Makassar, dalam rangka implementasi SIMTANAS (KKP Web), pihaknya haruslah meng-up date datadata pertanahan yang ada di wilayahnya, mencakup data fisik dan data yuridis suatu bidang tanah. Oleh karena itu, maka pihak Kantor Pertanahan harus mempersiapkan semua data manual yang ada untuk dituangkan dalam SIMTANAS (KKP Web). Dalam pelaksanaannya memang membutuhkan waktu dan tenaga yang tidak sedikit, namun untuk memberikan pelayanan prima kepada masyarakat dan untuk memperbaiki sistem supaya lebih maju dan berkembang, maka hal ini mutlak untuk dilaksanakan, terlebih lagi bahwa penerapan SIMTANAS ini merupakan perintah peraturan perundang-undangan.

Kehadiran SIMTANAS dapat menunjang akuntabilitas administrasi pertanahan. Adanya SIMTANAS ini diharapkan dapat menekan dan bahkan menghilangkan konflik-konflik pertanahan yang terjadi akibat dari administrasi pertanahan yang tidak efisien. Sebagai contoh adalah masalah sertifikat ganda. Masalah ini timbul akibat dari tidak efektifnya administrasi pertanahan yang dijalankan secara manual. Fenomena kasus sertifikat ganda secara garis besar lebih banyak disebabkan oleh kurangnya transparansi informasi mengenai kepemilikan tanah. Masyarakat sering kesulitan dalam mengakses informasi mengenai kepemilikan suatu luasan tanah di pedesaan dan atau suatu bidang tanah di wilayah perkotaan. Di samping itu, nilai ekonomis tanah mendorong seseorang untuk menguasai, menjaga dan mengamankan tanah miliknya dari penguasaan orang lain.

Sistem Informasi dan Manajemen Pertanahan Nasional (SIMTANAS) berisi tentang basis data kepemilikan tanah, baik yang dimiliki oleh pemerintah maupun perseorangan sehingga adanya SIMTANAS ini tentunya dapat mencegah 
munculnya sertifikat ganda. SIMTANAS dalam implementasinya yang berupa KKP Web membantu proses manajemen terhadap aktifitas dalam kegiatan pertanahan. Adanya KKP web ini memberikan semangat baru terhadap reforma agraria Indonesia mengingat banyaknya permasalahan agraria yang ada di Indonesia memerlukan penanganan yang serius.

Berdasarkan Keputusan Kepala BPN RI Nomor 277 Tahun 2012 tentang Sapta Tertib Pertanahan, indikator pelaksanaan tertibadministrasi pertanahan adalah menjalankan Komputerisasi Kantor Pertanahan (KKP) secara konsisten serta mengembangkan KKP ini. Tentunya dengan dijalankannya KKP ini dapat meningkat pola pelayanan pertanahan serta dapat mencegah hal-hal yang tidak diinginkan. Pola pelayanan yang berbasis komputer dengan KKP ini tentunya memiliki tingkat akuntabilitas yang lebih tinggi, misalnya dalam hal pemetaan tanah. Sistem komputerisasi ini dapat menyimpan peta tanah dalam jumlah yang lebih banyak dan juga mengurangi penyimpanan secara manual atau paperless.

Dengan demikian, sistem KKP ini dapat memberikan transparansi terhadap masyarakat umum. Pelayanan publik harus bersifat terbuka, mudah, dan dapat diakses oleh semua pihak yang membutuhkan dan disediakan secara memadai serta mudah dimengerti. Seperti halnya dalam implementasinya mencegah sertifikat ganda (overlapping), KKP ini berfungsi untuk memberikan data mengenai suatu bidang tanah yang telah bersertifikat ataupun belum bersertifikat. Dokumen yang akan diserahkan sebagai kelengkapan data untuk pendaftaran diserahkan ke server untuk dicek keabsahan datanya. Dalam pengecekan inilah digunakan aplikasi turunan dari KKP Web yang disebut Geospasial KKP. Permohonan yang masuk kemudian dicek dalam Geospasia KKP. Hal ini dimaksudkan agar tidak terjadi hal yang tidak diinginkan, salah satunya seperti sertifikat ganda.

SIMTANAS dengan segala aplikasi yang ada di dalamnya menyuguhkan informasi tentang kegiatan pertanahan secara transparan dan dalam waktu yang singkat sehingga selain menghemat waktu, aplikasi ini dapat pula menghemat biaya. KKP Web dan Geospasial KKP memiliki peranan penting dalam pencegahan sertifikat ganda. KKP Web mampu memberikan informasi menyeluruh tentang suatu bidang data tanpa memerlukan waktu yang lama, sedangkan Geospasial KKP dapat memberikan informasi letak dan gambar dari bidang-bidang tanah yang ada.

\section{Penutup}

Rangkaian proses pendaftaran tanah dilakukan guna mendapatkan sertifikat hak atas tanah. Pasal 19 ayat (2) huruf c Undang-Undang Pokok Agraria (UUPA) menguraikan bahwa pendaftaran tanah diakhiri dengan pemberian surat-surat tanda bukti hak yang berlaku sebagai alat pembuktian yang kuat. Ketentuan mengenai pendaftaran tanah lebih lanjut diatur dalam Pasal 3 huruf a jo. Pasal 4 ayat (1) Peraturan Pemerintah Nomor 24 Tahun 1997 tentang Pendaftaran Tanah yang menegaskan bahwa pendaftaran tanah bertujuan untuk memberikan kepastian dan perlindungan hukum kepada pemegang hak atas suatu bidang tanah, satuan rumah susun, dan hak-hak lain yang terdaftar agar dengan mudah dapat membuktikan dirinya sebagai pemegang hak yang bersangkutan, kepada pemegang hak yang bersangkutan diberikan hak atas tanah. Pemberian surat tanda bukti hak atas tanah tersebut dilakukan melalui penerbitan sertifikat.

Dibutuhkan akuntabilitas dalam penyelenggaraan administrasi pertanahan di Indonesia sehingga dapat meredam terjadinya konflik pertanahan di Indonesia. Akuntabilitas administrasi pertanahan ini didasarkan pada prinsip goodgovernance dan AsasAsas Umum Pemerintahan yang Baik. Melalui akuntabilitas administrasi pertanahan, akses terhadap informasi pertanahan akan terbuka sehingga setiap orang dapat mengakses informasi pertanahan tersebut. Akuntabilitas administrasi pertanahan dalam penerbitan sertifikat hak atas tanah diwujudkan dengan diterapkannya Sistem Informasi dan Manajemen Pertanahan Nasional (SIMTANAS) 
yang direalisasikan dalam bentuk bank data kegiatan pertanahan yang terpusat dan berbasis komputerisasi. SIMTANAS dalam implementasinya adalah Komputerisasi Kegiatan Pertanahan (KKP). Sistem KKP ini dapat memberikan transparansi terhadap masyarakat umum. Pelayanan publik harus bersifat terbuka, mudah, dan dapat diakses oleh semua pihak yang membutuhkan dan disediakan secara memadai serta mudah dimengerti. Seperti halnya dalam implementasinya mencegah sertifikat ganda (overlapping), KKP ini berfungsi untuk memberikan data mengenai suatu bidang tanah yang telah bersertifikat ataupun belum bersertifikat. Dokumen yang akan diserahkan sebagai kelengkapan data untuk pendaftaran diserahkan ke server untuk dicek keabsahan datanya. Dalam pengecekan inilah digunakan aplikasi turunan dari KKP Web yang disebut Geospasial KKP. Permohonan yang masuk kemudian dicek dalam Geospasia KKP. Hal ini dimaksudkan agar tidak terjadi hal yang tidak diinginkan, salah satunya seperti sertifikat ganda.

\section{DAFTAR PUSTAKA}

\section{A. Buku}

Ali, Faried, 1997, Hukum Tata Pemerintahan dan

Proses Legislatif Indonesia, Rajagrafindo Persada, Jakarta.

Fahmal, Muin, 2008, Peran Asas-Asas Umum Pemerintahan yang Layak dalam Mewujudkan Pemerintahan yang Bersih, Kreasi Total Media, Yogyakarta.

Hadjon, Philipus M.,et.al., 2010, Hukum Administrasi dan Good Governance, Universitas Trisakti, Jakarta.

Harsono, Boedi, 2005, Hukum Agraria Indonesia, Sejarah Pembentukan UndangUndang Pokok Agraria, Isi dan Pelaksanaannya, Djambatan, Jakarta.

Lubis, M. Yamin dan Abd. Rahim Lubis, 2011, Pencabutan Hak, Pembebasan, dan Pengadaan tanah, Bandung, Mandar Maju.

Nugroho D., Riant, 2003, Kebijakn Publik: Formulasi, Implementasi dan Evaluasi, Elex Media Komputindo, Jakarta.

Santoso,Urip, 2010, Pendaftaran dan Peralihan Hak Atas Tanah, cetakan ke 2, Kencana, Jakarta.

Sutedi, Adrian, 2009, Tinjauan Hukum Pertanahan, Pradnya Paramita, Jakarta.

Widodo, Joko, 2001, Good Governance; Telaah Dari Dimensi Akuntabilitas, Kontrol
Birokrasi Pada Era Desentralisasi Dan Otonomi Daerah, Insan Cendekia, Surabaya. Zaidar, 2009, Dasar Filosofi Hukum Agraria Indonesia, Pustaka Bangsa Press, Medan.

\section{B. Hasil Penelitian}

Morico, Meiji, 2007, Prinsip Transparansi dalam Pendaftaran Tanah di Kantor Pertanahan Kota Medan, Tesis, Universitas Sumatera Utara, Medan.

\section{Internet}

Yona Ramadhani, "Tata Kelola Pemerintahan yang Baik dan Bersih (Good and Clean Governance)", https://www. academia.edu/9966363/BAB_9_. Tata_Kelola_Pemerintahan_yang_ Baik_dan_Bersih_good_and_clean_ governance_?auto $=$ download, diakses pada tanggal 28 September 2016.

\section{Peraturan Perundang-Undangan}

Undang-Undang Nomor 5 Tahun 1960 tentang Peraturan Dasar Pokok-Pokok Agraria (Lembaran Negara Republik Indonesia Tahun 1960 Nomor 104, Tambahan Lembaran Negara Republik Indonesia Nomor 2043). 
Undang-Undang Nomor 26 Tahun 2007 tentang Penataan Ruang (Lembaran Negara Republik Indonesia Tahun 2007 Nomor 68, Tambahan Lembaran Negara Republik Indonesia Nomor 4725).

Undang-Undang Nomor 14 Tahun 2008 tentang Keterbukaan Informasi Publik (Lembaran Negara Republik Indonesia Tahun 2008 Nomor 3696, Tambahan Lembaran Negara Republik Indonesia Nomor 4846).
Peraturan Pemerintah Nomor 24 Tahun 1997 tentang Pendaftaran Tanah (Lembaran Negara Republik Indonesia Tahun 1997 Nomor 59, Tambahan Lembaran Negara Republik Indonesia Nomor 3696).

Keputusan Presiden Nomor 34 Tahun 2003 tentang Kebijakan Nasional di Bidang Pertanahan.

Ketetapan MPR Nomor IX/MPR/2001 tentang Pembaruan Agraria dan Pengelolaan Sumber Daya Alam. 